\title{
FAKTOR YANG BERHUBUNGAN DENGAN PEMBERIAN IMUNISASI TETANUS TOXOID PADA IBU HAMIL
}

\author{
Sutrisari Sabrina Nainggolan ${ }^{1 *}$, Junie Harista ${ }^{2}$ \\ ${ }^{1 *}$ Program Studi Profesi Ners STIK Bina Husada \\ Email : sutrisarisabrinanainggolan@gmail.com \\ ${ }^{2}$ Program Studi Kebidanan STIK Bina Husada
}

Email : junieharista@gmail.com

\section{ABSTRACT : FACTORS RELATED TO GIVING TETANUS TOXOID IMMUNIZATION IN PREGNANT WOMEN}

Background : Tetanus toxoid immunization in pregnant women is one of the recommended things before labor takes place in order to reduce the risk of death of a newborn fetus. In addition to reducing the risk of fetal death. Apart from reducing the risk of fetal death, this vaccine is also useful for preventing tetanus in babies. The spread of neonatal tetanus cases that occurred in eight districts / cities (47\%) in South Sumatra found that out of 11 reported cases $82 \%$ had never received TT immunization.

Purpose : the purpose of this research was to find out the factors associated with tetanus toxoid immunization.

Method: This research is in the form of a literature review. Search literature reviews through publications in three databases using the keywords ("associated factors" OR "related factors") AND (tetanus toxoid immunization OR tetanus toxoid immunization). From the search results, the researchers got articles through Google Scholar, Garuda Portal, Mendeley, and 474 articles using Science Direct that match these keywords. From the search results obtained, screening was carried out based on duplication, conformity with the title and inclusion criteria and study selection criteria. So that there are 2 articles that meet the criteria $(n=2)$.

Result : From 2 literatures that have met the inclusion and exclusion criteria, these two articles are a cross-sectional study, the study was conducted in Indonesia, using Indonesian. These two articles have different results regarding knowledge, attitudes and family support.

Conclusion : Factors related to tetanus toxoid immunization are knowledge, attitude and family support.

Keywords : related factors, tetanus toxoid immunization 
INTISARI : FAKTOR YANG BERHUBUNGAN DENGAN PEMBERIAN IMUNISASI TETANUS TOXOID PADA IBU HAMIL

Latar belakang : Imunisasi tetanus toksoid pada ibu hamil merupakan salah satu hal yang dianjurkan sebelum persalinan berlangsung guna menurunkan risiko kematian janin yang baru saja dilahirkan. Selain menurunkan risiko kematian janin. Selain menurunkan risiko kematian janin, vaksin ini juga berguna untuk mencegah tetanus pada bayi. Penyebaran kasus tetanus neonatorum yang terjadi di delapan kabupaten/kota (47\%) di Sumatera Selatan didapatkan bahwa dari 11 kasus yang terlaporkan $82 \%$ tidak pernah mendapat imunisasi TT.

Tujuan : diketahuinya faktor-faktor yang berhubungan dengan pemberian imunisasi tetanus toksoid.

Metode Penelitian : Penelitian ini berbentuk literature review. Pencarian literature review melalui publikasi di tiga database dengan menggunakan kata kunci ("associated factors" OR "faktor yang berhubungan") AND (imunisasi tetanus toxoid OR tetanus toxoid immunization). Dari hasil pencarian tersebut peneliti mendapatkan artikel melalui google scholar, portal garuda, Mendeley, dan 474 artikel menggunakan Science Direct yang sesuai dengan kata kunci tersebut. Dari hasil pencarian yang didapat selanjutnya dilakukan skrining berdasarkan duplikasi, kesesuaian dengan judul dan kriteria inklusi dan kriteria seleksi studi. Sehingga diperoleh 2 artikel yang memenuhi kriteria $(n=2)$.

Hasil : Dari 2 literatur yang telah memenuhi kriteria inklusi dan eksklusi, kedua artikel ini berupa cross-sectional study, penelitian dilakukan di Indonesia, menggunakan bahasa Indonesia. Kedua artikel ini memiliki hasil ulasan yang berbeda mengenai pengetahuan, sikap dan dukungan keluarga.

Kesimpulan : Faktor-faktor yang berhubungan dengan pemberian imunisasi tetanus toxoid yaitu pengetahuan, sikap dan dukungan keluarga.

Kata Kunci: Faktor Berhubungan, Imunisasi Tetanus Toxoid

\section{PENDAHULUAN}

Tetanus pada maternal merupakan penyebab kematian paling sering terjadi akibat persalinan yang tidak aman/steril atau berasal dari luka yang didapatkan ibu hamil sebelum melahirkan. Kaku otot yang nyeri yang disebabkan oleh neurotoxin yang dihasilkan oleh Clostridium tetani pada luka anaerob merupakan manisfestasi dari tetanus. Tetanus maternal terjadi pada kehamilan dan dalam 6 minggu setelah melahirkan. Angka kematian ibu dengan tetanus sangatlah tinggi, terutama ketika perawatan kesehatan yang tepat tidak tersedia (Kemenkes RI, 2012).
Untuk dapat mencegah tetanus maternal maka perlu dilakukan pemberian imunisasi. Penyelenggaraan imunisasi pada ibu hamil merupakan salah satu kelompok populasi yang menjadi sasaran imunisasi lanjutan, yaitu ulangan imunisasi dasar untuk mempertahankan tingkat kekebalan dan untuk memperpanjang usia perlindungan (Permenkes Nomor 12, 2017).

Cakupan imunisasi Td2+ pada ibu hamil tahun 2018 sebesar 51,76\%, relatif lebih rendah jika dibandingkan dengan tahun 2017 yang sebesar $65,3 \%$, juga lebih rendah sekitar $30 \%$ 
dibandingkan dengan cakupan pelayanan kesehatan ibu hamil K4 yang sebesar $88,03 \%$, sementara $\mathrm{Td} 2+$ merupakan syarat pelayanan kesehatan ibu hamil K4 (Kementerian Kesehatan Republik Indonesia, 2018).

Cakupan ibu hamil yang mendapatkan imunisasi TT di Puskesmas Boom Baru Palembang pada tahun 2013 sebanyak 245, sedangkan tahun 2014 mengalami penurunan drastis sebanyak 79 orang, sedangkan tahun 2015 dari bulan Januari sampai Oktober cakupan ibu hamil yang mendapatkan imunisasi TT sebanyak 53 orang. Dari 359 ibu hamil, 133 ibu hamil berpendidikan rendah, 114 tidak mendapatkan kelengkapan imunisasi tetanus toxoid. Sebagian besar ibu hamil (122 responden) memiliki sikap negatif. Oleh sebab itu, dapat disimpulkan bahwa terdapat hubungan antara pendidikan dan sikap ibu dengan kelengkapan imunisasi tetanus toxoid (Yunica, 2015).

Faktor yang berhubungan dengan imunisasi tetanus toxoid dua (TT2) pada ibu hamil trimester tiga di Puskesmas Kemuning Desa Cimanggis Kecamatan Bojong Gede Kabupaten Bogor Provinsi Jawa Barat 2016 menunjukkan bahwa sebanyak 23 $(51,1 \%) \quad$ responden yang berpengetahuan kurang, 26 (57,8\%) responden yang mendapatkan media informasi dari media cetak, 24 (53,5\%) responden yang tidak ada dukungan suami dan sebanyak $27 \quad(60 \%)$ responden tidak ada ketersediaan obat. Sehingga didapatkan hubungan yang signifikan antara pengetahuan, media informasi, dukungan suami, dan ketersediaan obat dengan imunisasi tetanus toksoid dua pada ibu hamil trimester (Nurmawati dan Munawaroh, 2016).

Pemanfaatan imunisasi TT di antara wanita usia subur di kota
Dukem, Ethiopia Timur masih rendah. Pendidikan ibu, paparan media, layanan tindak lanjut ANC, jadwal vaksinasi, jarak dari fasilitas kesehatan, dan tempat persalinan merupakan prediktor yang signifikan dari pemanfaatan imunisasi TT. Pembuat kebijakan dan pemangku kepentingan lainnya harus mempertimbangkan kebutuhan untuk memastikan akses ke pendidikan ibu (Anatea, Mekonnen, Dachew, 2018).

Persentase cakupan imunisasi tetanus toxoid pada ibu hamil di Puskesmas Siantan Hilir Kota Pontianak tahun 2017 yaitu 610 jumlah ibu hamil yang melakukan TT2+ sebanyak $233(38,20 \%)$ orang. Cakupan imunisasi TT2+ pada ibu hamil di Puskesmas Siantan Hilir tahun 2018 sebesar 74 ibu hamil yang melakukan imunisasi tetanus toxoid. Faktor usia, pendidikan, paritas, pengetahuan, dukungan suami, dukungan petugas kesehatan mempengaruhi ibu hamil untuk melakukan imunisasi tetanus toxoid, sedangkan faktor ekonomi dan faktor media informasi tidak mempengaruhi ibu hamil untuk melakukan imunisasi tetanus toxoid (Alexander dan Putri, 2019).

Tingkat prevalensi penerima imunisasi TT dan dosis yang memadai lebih tinggi di antara wanita hamil di Sierra Leone. Temuan dari penelitian ini menunjukkan bahwa wanita hamil dengan usia berumur, yang di tinggal di wilayah utara dan selatan Sierra Leonne, wanita dari etnis Temba, wanita dengan sosial ekonomi rumah tangga yang tinggi, wanita dengan paritas lebih tinggi, mereka yang terpapar media massa (radio, tv, dan ponsel) serta mereka yang menghadiri setidaknya empat kali kunjungan ANC memiliki peluang lebih tinggi untuk menerima imunisasi TT dan dosis yang memadai. Namun, perempuan dengan 
tingkat pendidikan dasar dan lebih tinggi memiliki peluang lebih rendah untuk menerima imunisasi TT jika dibandingkan dengan mereka yang tidak berpendidikan formal (Yaya, et all, 2020).

Data secara nasional maupun internasional masih menunjukkan cakupan imunisasi TT yang relatif rendah. Banyak faktor yang

\section{METODE}

Penelitian ini berbentuk literature review. Pencarian literature review melalui publikasi di tiga database dengan menggunakan kata kunci ("associated factors" OR "faktor yang berhubungan") AND (imunisasi tetanus toxoid OR tetanus toxoid immunization). Dari hasil pencarian tersebut peneliti mendapatkan artikel sebanyak 248 menggunakan google scholar, 13 artikel menggunakan portal garuda, 11 artikel menggunakan Mendeley, dan 474 artikel

HASIL

Dari 2 literatur yang telah memenuhi kriteria inklusi dan eksklusi, kedua artikel ini berupa cross-sectional study, penelitian kemungkinan berperan dalam pemberian imunisasi tetanus toxoid. Hal inilah yang menjadi latar belakang sehingga penulis tertarik untuk meneliti mengenai faktor-faktor yang berhubungan dengan pemberian imunisasi tetanus toxoid pada ibu hamil.

menggunakan Science Direct yang sesuai dengan kata kunci tersebut. Dari hasil pencarian yang didapat selanjutnya dilakukan skrining berdasarkan duplikasi, didapatkan 684 artikel yang terduplikasi, kemudian artikel tersebut diskrining berdasarkan kesesuai dengan judul tersisa 4 artikel, berikutnya artikel tersebut dilakukan skrining berdasarkan kriteria inklusi dan kriteria seleksi studi, sehingga memperoleh 2 artikel yang memenuhi kriteria $(n=2)$.

dilakukan di Indonesia, menggunakan bahasa Indonesia. Tabel 1 memperlihatkan karakteristik dari 2 jurnal yang digunakan dalam penelitian ini.

Tabel 1. Karakteristik jurnal berdasarkan penulis, tahun, judul, tempat, metode dan ringkasan hasil penelitian

\begin{tabular}{|c|c|c|c|}
\hline $\begin{array}{l}\text { Penulis Jurnal } \\
\text { (Tahun) dan Judul }\end{array}$ & $\begin{array}{l}\text { Tempat } \\
\text { Penelitian }\end{array}$ & Jenis Penelitian & Hasil Penelitian \\
\hline Meriem Meisyaroh & Puskesmas & \multirow[t]{9}{*}{ Cross sectional } & \multirow{9}{*}{$\begin{array}{l}\text { Terdapat } \\
\text { hubungan antara } \\
\text { pengetahuan }(p- \\
\text { value }=0,002), \\
\text { sikap }(p \text {-value }= \\
0,000) \text { dan } \\
\text { dukungan keluarga } \\
(p \text {-value }=0,000)\end{array}$} \\
\hline Syamson, Fadriyanto & Rappang & & \\
\hline (2018) & Kabupaten & & \\
\hline Faktor Yang & Sidrap & & \\
\hline Berhubungan Dengan & & & \\
\hline Pemberian Imunisasi & & & \\
\hline Tetanus Toxoid (TT) & & & \\
\hline Pada Ibu Hamil di & & & \\
\hline Wilayah Kerja & & & \\
\hline
\end{tabular}


TAHUN [MANUJU: MALAHAYATI NURSING JOURNAL, P- ISSN: 2655-2728

2021 E-ISSN: 2655-4712 VOLUME 3 NOMOR 3 TAHUN 2021] HAL 307-317

\begin{tabular}{|c|c|c|}
\hline $\begin{array}{l}\text { Puskesmas Rappang } \\
\text { Kabupaten Sidrap } \\
\text { Tahun } 2017\end{array}$ & & $\begin{array}{l}\text { dengan pemberian } \\
\text { imunisasi TT }\end{array}$ \\
\hline $\begin{array}{l}\text { Andi Nurlaily, Ely } \\
\text { Kurniati (2018) } \\
\text { Factors Related To } \\
\text { The Coverage Of } \\
\text { Tetanus Toxoid } \\
\text { Immunization For } \\
\text { Pregnant Women }\end{array}$ & $\begin{array}{ll}\text { Puskesmas } & \text { Cross sectional } \\
\text { Bonto Tiro } & \end{array}$ & $\begin{array}{l}\text { Faktor yang } \\
\text { berhubungan } \\
\text { dengan pemberian } \\
\text { imunisasi tetanus } \\
\text { toxoid yaitu } \\
\text { pengetahuan }(p- \\
\text { value }=0,022) \text { dan } \\
\text { pendidikan }(p- \\
\text { value }=0,000) \\
\text { Sedangkan sikap } \\
(p \text {-value }=1,000), \\
\text { pekerjaan }(p \text {-value } \\
=0,553) \text { dan } \\
\text { dukungan keluarga } \\
\text { ( } p \text {-value = 1,000) } \\
\text { tidak terdapat } \\
\text { hubungan dengan } \\
\text { cakupan } \\
\text { pemberian } \\
\text { imunisasi tetanus } \\
\text { toxoid pada ibu } \\
\text { hamil }\end{array}$ \\
\hline
\end{tabular}

\section{PEMBAHASAN}

Kajian penelitian ini meliputi gambaran karakteristik responden, gambaran pemberian imunisasi tetanus toxoid, dan faktor yang berhubungan dengan pemberian imunisasi tetanus toxoid.

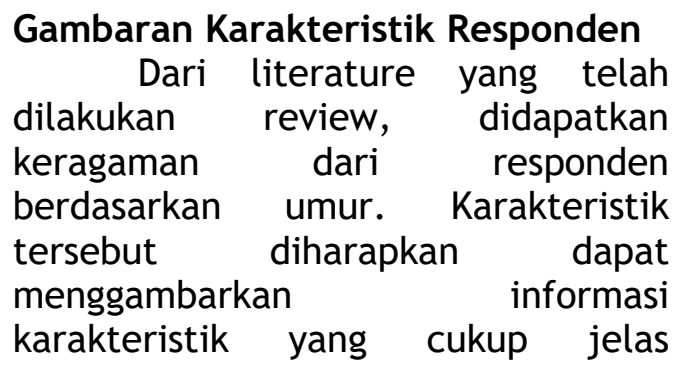
mengenai kondisi dari responden dan kaitannya dengan masalah dan tujuan penelitian. Pada artikel pertama, didapatkan umur 20-22 tahun sebanyak 5 orang $(16,7 \%)$, umur $23-25$ sebanyak 7 orang dengan persentase $(23,3 \%)$, umur $26-28$ sebanyak 6 orang dengan persentase $(20,0 \%)$, umur 29 31 sebanyak 2 orang dengan persentase $(6,7 \%)$, umur 32-34 sebanyak 3 orang dengan presentase (10,0\%), dan umur 35-37 sebanyak 7 orang dengan presentase $(23,3 \%)$ (Syamson \& Fadriyanto, 2017). Sedangkan untuk artikel kedua, umur diklasifikasikan menjadi dewasa awal sebanyak 26 orang $(49,1 \%)$ dan dewasa tengah sebanyak 27 orang $(50,9 \%)$ (Nurlaily \& Kurniati, 2018).

Usia tidak menunjukkan hubungan yang bermakna. Hal ini dimungkinkan karena umur ibu bukanlah merupakan faktor yang dominan, namun masih dipengaruhi oleh faktor-faktor lain. Sekalipun sisi umur cukup tingkat kematangannya, 
tetapi dari sisi pendidikan kurang, akhirnya berdampak terhadap kurangnya pengetahuan ibu (Suhartini \& Ahmad, 2015).

Usia $\geq 20$ tahun merupakan usia yang matang bagi seorang wanita untuk memiliki anak sehingga ibu lebih siap dan mengerti apa saja yang harus dilakukan di masa kehamilannya yang terbaik untuk ibu dan calon bayi yang akan dilahirkan. Usia yang sudah dewasa memiliki pengalaman hidup dibandingkan dengan usia di bawah 20 tahun, yang masih menuntut ilmu (Triratnasari, 2017). Semakin bertambahnya umur ibu hamil, maka diharapkan sikap ibu hamil dalam pelaksanaan imunisasi tetanus toxoid akan semakin positif sehingga nantinya akan membentuk perilaku dalam pelaksanaan imunisasi tetanus toxoid yang lebih baik lagi (Alexander \& Putri, 2019).

Hurlock (2005) dalam bukunya menyatakan bahwa semakin cukup umur dan kekuatan seseorang tingkat kematangan dan kekuatan seseorang akan lebih matang dalam berpikir dan bekerja. Dari segi kepercayaan masyarakat seseorang akan lebih dewasa dan lebih dipercaya dari orang yang belum cukup tingkat kedewasaannya. Hal ini sebagai akibat dari pengalaman dan kematangan jiwanya.

Berdasarkan uraian di atas, maka semakin cukup umur, maka tingkat kematangan, daya tangkap, pola pikir dan kekuatan seseorang akan lebih matang dalam berpikir dan bekerja. Pertambahan usia seseorang akan mengalami perubahan pada aspek fisik dan psikologisnya. Pada aspek psikologis, taraf berpikir seseorang akan semakin matang dan dewasa sehingga pengetahuan yang diperoleh pun semakin banyak.

\section{Gambaran Pemberian Imunisasi Tetanus Toxoid}

Pemberian imunisasi tetanus toxoid pada kedua artikel menjelaskan ibu hamil yang tidak lengkap atau lengkap imunisasi TT, sehingga dari kedua jurnal diharapkan dapat menggambarkan informasi yang cukup jelas mengenai kondisi dari responden serta kaitannya dengan masalah dan tujuan penelitian.

Pada artikel pertama, didapatkan imunisasi TT lengkap sebanyak 10 orang $(33,3 \%)$, imunisasi tidak lengkap sebanyak 20 orang dengan persentase $(66,7 \%)$. Dari studi pendahuluan yang dilakukan oleh peneliti, status imunisasi TT kurang lengkap sehubungan dengan pengetahuan ibu hamil tentang manfaat dan waktu pemberian imunisasi TT masih kurang, dan sikap ibu hamil terhadap imunisasi TT menunjukkan tidak peduli, adapun dukungan keluarga kurang menyakinkan kepada ibu hamil terhadap imunisasi TT (Syamson \& Fadriyanto, 2017).

Ada satu ibu hamil yang ada di wilayah kerja Puskesmas Rurukan tahu tentang arti dan manfaat imunisasi TT akan tetapi tidak dilaksanakan karena kesibukan pekerjaan. Selain itu, lima orang ibu yang mempunyai bayi 0-1 tahun didapatkan bahwa tiga ibu tidak tahu arti dan manfaat imunisasi TT karena selama hamil hanya satu kali memeriksakan kehamilan, satu ibu lagi mengatakan tahu arti imunisasi TT tapi menurunya imunisasi TT tidak terlalu penting untuk kehamilan karena setiap hari sudah mengkonsumsi vitamin dan tablet tambah darah, sedangkan satu ibu lainnya mengatakan selain tidak mengerti tentang manfaat $T T$, juga karena takut disuntik (Manutu, Korah \& Pesak, 2013). 
Sasaran ibu hamil di wilayah kerja Puskesmas Wundulako pada tahun 216 sebanyak 152 orang. Berdasarkan sasaran tersebut, target pemberian imunisasi TT1 sebanyak 126 $(82,9 \%)$ dengan cakupan sebanyak 59 $(38,8 \%)$. Target pemberian imunisasi TT2 pada ibu hamil yang dicapai sebanyak $96(63,2 \%)$ dengan cakupan sebanyak 63 (41,5\%). Target pemberian imunisasi TT3 pada ibu hamil yang dicapai sebanyak 107 $(70,4 \%)$ dengan cakupan sebanyak 46 (30,3\%). Target pemberian imunisasi TT4 pada ibu hamil yang dicapai sebanyak $101(66,4 \%)$ dengan cakupan sebanyak 37 (24,3\%). Sedangkan target pemberian imunisasi TT5 pada ibu hamil yang dicapai sebanyak 94 $(61,8 \%)$ dengan cakupan sebanyak 40 (26,3\%) (Sarmita, 2017).

Sedangkan untuk artikel kedua, imunisasi TT lengkap sebanyak 20 orang $(37,7 \%)$, imunisasi tidak lengkap sebanyak33 orang dengan persentase $(62,3 \%)$. Dari data yang ada didapatkan bahwa tahun 2015 dari jumlah ibu hamil sebanyak 437 orang sedangkan cakupan pemberian imunisasi TT1 sebesar 122 orang (54,7\%), imunisasi TT2 sebesar 63 orang (7,2\%). Pada tahun 2016 Januari - September jumlah ibu hamil sebanyak 380 sedangkan cakupan pemerian imunisasi TT1 sebanyak 85 orang $(9,0 \%)$, TT2 sebanyak 32 orang $(4,3 \%)$. Pada periode bulan November 2016 - Januari 2017 jumlah ibu hamil sebanyak 114 orang sedangkan cakupan pemberian imunisasi TT1 sebanyak 26 orang $(3,8 \%)$, TT2 sebanyak 17 orang $(2,0 \%)$. Ini menunjukkan adanya penurunan pemberian imunisasi TT (Nurlaily \& Kurniati, 2018).

Cakupan imunisasi TT pada ibu hamil di Kabupaten Sukoharjo mengalami fluktuasi secara signifikan setiap tahunnya. Cakupan imunisasi pada ibu hamil pada tahun 2016 dan 2017, angka cakupan imunisasi TT pada 12 kecamatan yang ada di Kabupaten Sukoharjo tidak ada yang memenuhi target imunisasi oleh pemerintah yaitu sebesar $80 \%$ (Indriaswuri, 2019).

Berdasarkan uraian di atas, maka kami dapat simpulkan bahwa pemberian imunisasi TT pada ibu hamil belum mencapai target. Imunisasi TT sangat penting untuk diberikan kepada ibu hamil. Hal ini dilakukan agar ibu mendapatkan kekebalan tubuh, mencegah penyakit yang disebabkan oleh infeksi tetanus pada ibu hamil dan bayi, sehingga memberikan perlindungan pada ibu dan bayi yang baru lahir.

Faktor Yang Berhubungan Dengan Pemberian Imunisasi Tetanus Toxoid Yang berhubungan dengan pemberian imunisasi tetanus toxoid pada penelitian (Syamson \& Fadriyanto, 2017), pengetahuan (nilai $p=0,002$ ), sikap (nilai $p=0,000$ ), dan dukungan keluarga (nilai $p=0,000$ ) memiliki hubungan yang signifikan dengan pemberian imunisasi tetanus toxoid. Kurangnya daya ingat/hafalan, salah menafsirkan informasi keterbatasan kognitif, kurang berminat dan tidak familiar terhadap sumber daya informasi sangat berkaitan dengan pengetahuan. Pengetahuan yang baik akan membentuk sikap. Sikap menentukan seseorang ke arah yang lebih baik. Sikap positif akan memunculkan perilaku ibu hamil yang akan melakukan imunisasi TT baik di puskesmas maupun di posyandu untuk memanfaatkan segala pemberian imunisasi TT pada ibu hamil. Begitu pula halnya dengan dukungan keluarga. Dukungan keluarga 
merupakan dukungan yang paling diharapkan ibu hamil dalam melengkapi imunisasi TT. Semakin baik dukungan yang diberikan keluarga terhadap ibu hamil maka dapat meningkatkan motivasi untuk melengkapi imunisasi TT.

Hal yang berbeda dari artikel Nurlaily \& Kurniati (2018), faktor yang berhubungan dengan pemberian imunisasi tetanus toxoid adalah pendidikan dengan nilai $\mathrm{p}=0,000$. Sedangkan untuk pengetahuan (nilai $p$ $=0,022$ ), sikap (nilai $p=1,000$ ), pekerjaan (nilai $\mathrm{p}=0,553$ ) dan dukungan keluarga (nilai $p=1,000$ ) tidak memiliki hubungan yang signifikan dengan pemberian imunisasi tetanus toxoid. Semakin tinggi pendidikan seseorang semakin mudah menerima informasi sehingga makin banyak pengetahuan ibu yang dimiliki sebaiknya semakin rendah pendidikannya akan menghambat sikap dan perilaku seseorang terhadap nilai-nilai kesehatan dan kurangnya pengetahuan ibu tentang imunisasi tetanus toksoid mengakibatkan ibu kurang mengetahui bahaya dari penyakit tetanus yang dapat membahayakan ibu dan janin. Namun yang terjadi, sebagian dari ibu hamil tidak dapat memahami pentingnya melakukan imunisasi tetanus toksoid sehingga tidak mendukung sikap positif pada ibu hamil. Sikap positif ini masih kurang pada ibu hamil dikarenakan kebanyakan ibu hamil malas dengan jarak fasilitas kesehatan yang jauh serta petugas kesehatan yang jarang ada di tempat. Pekerjaan tidak mempengaruhi cakupan pemberian imunisasi pada ibu hamil karena ibu yang bekerja ataupun tidak bekerja, jika tidak memiliki pengetahuan dan mendapatkan informasi tentang pentingnya melakukan imunisasi tetanus toksoid, maka keduanya tetap tidak melakukan imunisasi secara lengkap. Selain itu, dukungan keluarga yang telah diberikan kepada ibu hamil belum tentu menjadi penentu ibu hamil untuk melakukan imunisasi tetanus toksoid karena ibu hamil sendiri tidak memiliki keinginan atau tidak memperdulikan pentingnya imunisasi tetanus toksoid.

Peningkatan pengetahuan tidak mutlak diperoleh dari pendidikan formal saja, akan tetapi juga dapat diperoleh dari pendidikan non formal. Semakin tinggi tingkat pendidikan seseorang maka semakin tinggi pula motivasi untuk memanfaatkan fasilitas kesehatan karena telah memiliki pengetahuan dan wawasan yang lebih luar. Sehingga tingkat pendidikan ibu hamil dapat mempengaruhi ibu dalam mengambil keputusan untuk melakukan pemberian imunisasi TT. Sebagian besar ibu yang melakukan suntik imunisasi $T T$ berpengetahuan tinggi maka mereka mampu menyikapi dengan baik untuk melakukan suntik imunisasi TT. Sikap terbentuk karena ibu memiliki pengetahuan yang baik, dimana ibu yang memiliki pengetahuan yang baik maka akan mampu menyikapi segal hal dengan baik pula (Sepiwiryanti, 2014).

Pendidikan mempengaruhi daya intelektual seseorang dalam memutuskan suatu hal. Ibu yang tidak mengenyam pendidikan tinggi menyebabkan daya intelektualnya menjadi kurang sehingga kepatuhan ibu dalam melaksanakan kepatuhan imunisasi TT akan bergantung pada perilaku orang-orang sekitarnya seperti suami atau orang tua (Sari, 2019).

Hal yang sama juga diungkapkan oleh Daryanti (2019), bahwa orang yang memiliki pendidikan 
lebih tinggi adalah orang yang mempunyai wawasan yang lebih luas terutama tentang arti pentingnya kesehatan. Tingginya kesadaran akan pentingnya kesehatan dapat mendorong orang yang bersangkutan untuk melakukan tindakan yang lebih baik. Jika seorang mempunyai pengetahuan baik khususnya mengenai imunisasi, maka orang tersebut akan patuh untuk melaksanakan imunisasi TT. Dari pengetahuan ini, akan membentuk sikap pengalaman pribadi. Sikap akan lebih mudah terbentuk apabila pengalaman pribadi tersebut terjadi dalam situasi yang melibatkan faktor emosional. Lingkungan juga dapat mempengaruhi seseorang sehingga dapat termotivasi untuk melakukan sesuatu. Selain keluarga, lingkungan juga mempunyai peran yang besar dalam memotivasi seseorang dalam merubah tingkah lakunya.

Berdasarkan uraian di atas, maka pendidikan tinggi memiliki

\section{KESIMPULAN}

Pertambahan usia seseorang akan mengalami perubahan pada aspek fisik dan psikologisnya. Pada aspek psikologis, taraf berpikir seseorang akan semakin matang dan dewasa sehingga pengetahuan yang diperoleh pun semakin banyak. Imunisasi TT sangat penting untuk diberikan kepada ibu hamil untuk memberikan perlindungan pada ibu dan bayi yang baru lahir. Semakin tinggi pendidikan seseorang semakin mudah menerima informasi sehingga wawasan lebih luas karena tingkatan pendidikan yang lebih tinggi dan akses informasi yang lebih luas membuat ibu mendapatkan pengalaman dari yang telah mengetahui tentang imunisasi tetanus toxoid. Pengetahuan menjadi hal penting yang harus diperhatikan untuk memunculkan sikap positif pada ibu hamil, sehingga akan memunculkan perilaku ibu hamil untuk melakukan imunisasi tetanus toxoid saat kehamilan. Perilaku ibu hamil untuk melakukan imunisasi tetanus toxoid juga perlu mendapatkan perhatian khusus dari keluarga dalam mendukung pencapaian keberhasilan imunisasi TT. Dukungan keluarga tersebut dapat diwujudkan dengan memberikan motivasi pada ibu hamil untuk datang melakukan imunisasi tetanus toxoid. Hal ini disebabkan karena keluarga merupakan orang yang terdekat yang mampu memberikan motivasi pada proses imunisasi tetanus toxoid.

makin banyak pengetahuan ibu yang dimiliki. Namun yang terjadi, sebagian dari ibu hamil tidak dapat memahami pentingnya melakukan imunisasi tetanus toksoid sehingga tidak mendukung sikap positif pada ibu hamil. Selain itu, dukungan keluarga yang telah diberikan kepada ibu hamil belum tentu menjadi penentu ibu hamil untuk melakukan imunisasi tetanus toksoid karena ibu hamil sendiri tidak memiliki keinginan atau tidak memperdulikan pentingnya imunisasi tetanus toksoid. 


\section{DAFTAR PUSTAKA}

Alexander \& Putri, T.A. (2019). Faktor-Faktor Yang Mempengaruhi Ibu Hamil Dalam Melakukan Imunisasi Tetanus Toxoid Di Puskesmas Siantan Hilir Kota Pontianak Tahun $2019 . \quad$ Jurnal Kebidanan. ISSN : 2552-8121 : 323-340

Anatea, M.D., Mekonnen, T.H., \& Dachew, B.A. (2018). Determinants and Perceptions of the utilization of tetanus toxoid immunization among reproductive-age women in Dukem Town, Eastern Ethiopia : a community-based cross-sectional study. BMC International Health and Human Rights $18: 27$

Daryanti. (2019). Faktor-Faktor Yang Berhubungan Dengan Kelengkapan Imunisasi Tetanus Toxoid Pada Ibu Hamil di Wilayah Kerja Puskesmas Cilimus Kabupaten Garut Tahun 2019.

Hurlock. (2005). Psikologi perkembangan. Edisi 5. Jakarta : Erlangga.

Indriaswuri. (2019). Gambaran Cakupan Pemberian Imunisasi Tetanus Toxoid (TT) Pada Ibu Hamil Di Kabupaten Sukoharjo. Skripsi diterbitkan. Surakarta : Program Studi S1 Keperawatan.

Kementerian Kesehatan Republik Indonesia. (2012). Buletin Jendela Data dan Informasi Kesehatan : Elimininasi Tetanus Maternal dan Neonatal. Jakarta: Bakti Husada
Manutu, J., Korah, B.H., \& Pesak, E. (2013). Hubungan Pengetahuan Ibu Dengan Pemberian Imunisasi Tetanus Toxoid di Puskesmas Rurukan Kecamatan Tomohon Timur Kota Tomohon. Jurnal IImiah Bidan. (Online), Volume I, Nomor 1, ISSN : 2339 - 1731 : $31-35$.

Nurlaily, A. \& Kurniati, E. (2018). Factors Related To The Coverage Of Tetanus Toxoid Immunization For Pregnant Women. Jurnal Life Birth. (Online), Volume 2, Nomor 1, April 2018, p-ISSN : 2580-0574 : 30-44.

Nurmawati \& Munawaroh. (2016). Faktor-Faktor Yang Berhubungan Dengan Imunisasi Tetanus Toksoid Dua (TT2) Pada Ibu Hamil Trimester Tiga Di Puskesmas Kemuning Desa Cimanggis Kecamatan Bojong Gede Kabupaten Bogor Provinsi Jawa Barat 2016. Jurnal IImu dan Budaya, Vol.40, No.55, 6405-6420.

Peraturan Menteri Kesehatan Republik Indonesia Nomor 12 Tahun 2017 tentang Penyelenggaraan Imunisasi.

Sari, Sukma Intan. (2019). Hubungan Tingkat Pendidikan Ibu Hamil Dengan Perilaku Kepatuhan Dalam Melakukan Imunisasi Tetanus Toksoid (TT) Di Puskesmas Kecamatan Kramat Jati Jakarta Timur. Skripsi tidak diterbitkan. Jakarta : Universitas Binawan.

Sarmita. (2017). Gambaran Umum Tentang Pemberian Imunisasi 
Tetanus Toksoid (TT) Pada Ibu Hamil di Puskesmas Wundulako Kabupaten Kolaka Tahun 2016. KTI tidak diterbitkan. Kendari : Jurusan Kebidanan Politeknik Kesehatan Kendari.

Sepiwiryanti, Wika. (2014). Hubungan Pendidikan dan Pengetahuan Dengan Pemberian Imunisasi Tetanus Toksoid (TT) Pada Ibu Hamil Di Rumah Bersalin Mitra Ananda. Jurnal Kesehatan Abdurahman (Online), Volume 3, No.2 : 26-32.

Suhartini \& Ahmad. (2015). Hubungan Karakteristik Ibu Hamil Dengan Pengetahuan Tentang Imunisasi TT2+ Di Desa Pasarkeong Kecamatan Cibadak Kabupaten Lebak Tahun 2015. Jurnal Medikes, Volume 2, Edisi 2, November 2016 : 131-142.

Syamson, M.M., \& Fadriyanto. (2018). Faktor Yang Berhubungan Dengan Pemberian Imunisasi Tetanus Toxoid (TT) Pada Ibu
Hamil Di Wilayah Kerja Puskesmas Rappang Kabupaten Sidrap Tahun 2017. Jurnal Ilmiah Kesehatan Diagnosis Volume 12 Nomor 2, elSSSN : 2302-2531 : 177 281.

Triratnasari, Diah. (2017). Faktor Yang Berhubungan Dengan Pelaksanaan Imunisasi Tetanus Difteri Pada Ibu Hamil. Jurnal Berkala Epidemiologi, Volume 5 Nomor 3, hlm. 325-337.

Yaya, et all. (2020). Prevalence and Predictors of Taking Tetanus Toxoid Vaccine in Pregnancy : a cross sectional study of 8.722 women in Sierra Leone.

Yunica, J.A. (2015). Hubungan Pendidikan dan Sikap Ibu Hamil Dengan Kelengkapan Imunisasi Tetanus Toxoid (TT) Pada Ibu Hamil Di Puskesmas Boom Baru Palembang Tahun 2015. Jurnal Kesehatan Volume XI No.1 Juni 2016, ISSN 0126-107X 